\title{
ENDOSCOPIC RESECTION OF GIANT ETHMOIDAL OSTEOMA WITH INTRAORBITAL EXTENSION
}

\author{
Somu L1, Prasanna Kumar S2, Ravi Kumar A33, Shameem Shinaz ${ }^{4}$
}

\section{HOW TO CITE THIS ARTICLE:}

Somu L, Prasanna Kumar S, Ravi Kumar A, Shameem Shinaz."Endoscopic Resection of Giant Ethmoidal Osteoma with Intraorbital Extension". Journal of Evolution of Medical and Dental Sciences 2014; Vol. 3, Issue 68, December 08; Page: 14713-14717, DOI: 10.14260/jemds/2014/3976

\begin{abstract}
Osteomas are slow growing benign tumors of the paranasal sinuses. Most of them are asymptomatic and are discovered incidentally on radiographs. Sometimes they may grow to produce symptoms like cosmetic deformity, proptosis, epiphora and visual disturbances. A case of giant ethmoid osteoma with intra orbital extension in 30 year old female that was managed endoscopically is discussed. CONCLUSION: Endoscopic approach along with intra nasal drill is a safe and effective technique in management of osteoma of nose and paranasal sinus.
\end{abstract}

KEYWORDS: Osteoma, orbital involvement, endoscopic approach, intra nasal drill.

INTRODUCTION: Osteoma of paranasal sinus is a benign tumor that is more common in frontal and ethmoid sinus when compared to maxillary and sphenoid sinus.(1,2) Osteomas are usually asymptomatic. Surgery is indicated in symptomatic osteomas. The surgical options available is either external or endoscopic approach depending in the extent and complication involved. Endoscopic trans-nasal resection is ideal if the tumor is limited to the paranasal sinus and nasal cavity.(3) The main advantage being better cosmesis, shorter operative time and no major complications.

CASE REPORT: A 30-year-old female patient presented with history of left-sided facial pain for 4 years, left sided nasal block for the past 6 months and blurring of vision for the past 4 months. She gave history of attempted surgical excision of the nasal mass 3 weeks back. Examination revealed proptosis of left eyes (Fig 1). No obvious mass seen on anterior rhinoscopy. Nasal endoscopy showed a globular irregular mass that was seen medial to the middle turbinate on the left side.(Fig 2) The rest of the head and neck examination was unremarkable.

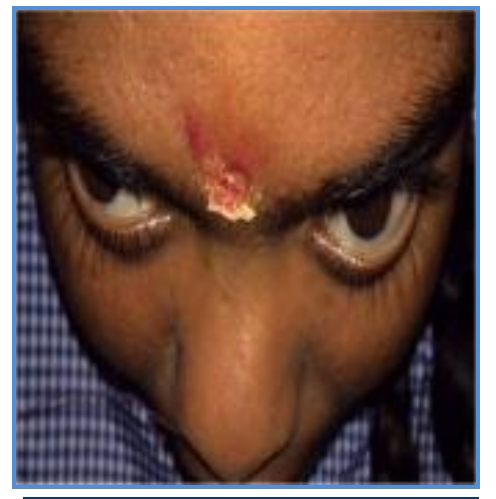

Fig. 1: Proptosis of left eye

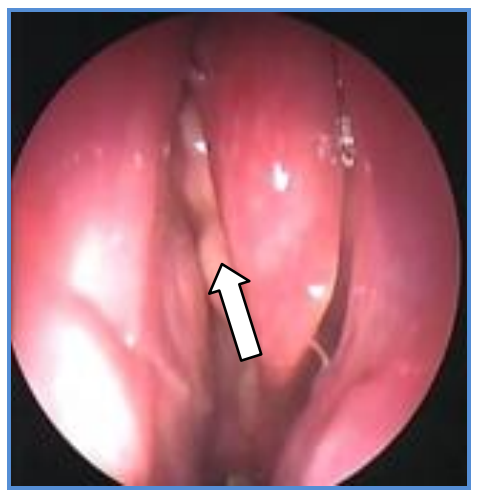

Fig. 2: Pre op Diagnostic Nasal Endoscopy 


\section{CASE REPORT}

Subsequent computed tomography scan of the paranasal sinuses revealed a $5.7 \times 5.2 \times 3.8 \mathrm{~cm}$ large osseous lesion originating from the left middle ethmoidal sinus encroaching into infero-medial quadrant of left orbit up to the globe with optic nerve compression. (Fig 3, 4) It also showed retained secretions and mucosal thickening in the left maxillary sinus. These findings strongly suggested the possibility of a giant osteoma.

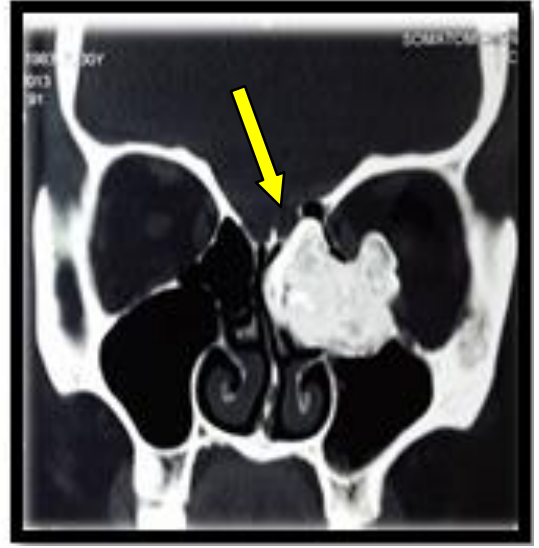

Fig. 3: CT PNS (CORONAL) showing involvement of fovea ethmoidalis and frontal recess with intra orbital extension

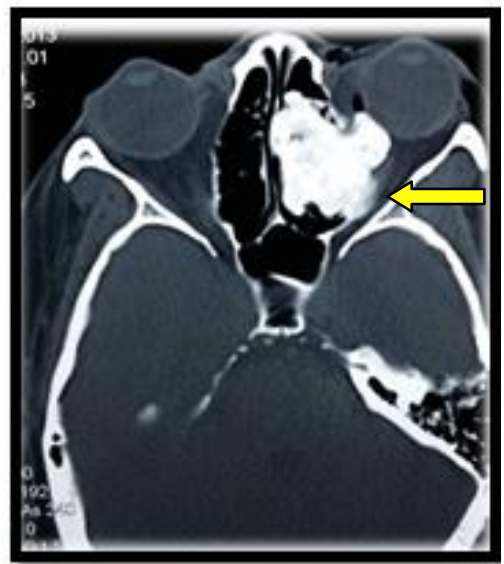

Fig. 4: CT PNS (AXIAL) showing the extent of tumor impinging on the optic nerve

Patient was planned and underwent endoscopic removal of the mass. Intra operatively, a globular mass was seen lateral to the middle turbinate extending in to the anterior and posterior ethmoids involving the fovea ethmoidalis and up to the sphenoid postero-superiorly. It was also extending laterally into the orbit through the lamina papyracea. Incision was made on the overlying mucosa which was elevated exposing the mass in the nasal cavity. The entire bony mass was carefully mobilized into the left nasal cavity. Since it was huge, it was broken into pieces and was delivered through the anterior nares (Fig 5). After achieving hemostasis, the area was thoroughly inspected and there was no evidence of CSF leakage. The postoperative period was uneventful.

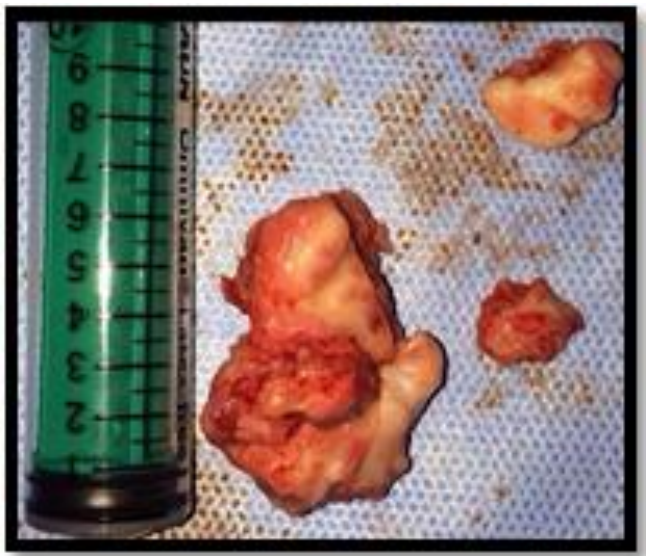

Fig. 5: Post- operative picture of the excised specimen 


\section{CASE REPORT}

Histologic examination revealed benign osteoid islands surrounded by dense fibrous tissue (Fig 6). A post op CT done 6 months later shows no evidence of residual or recurrent disease (Fig 7).

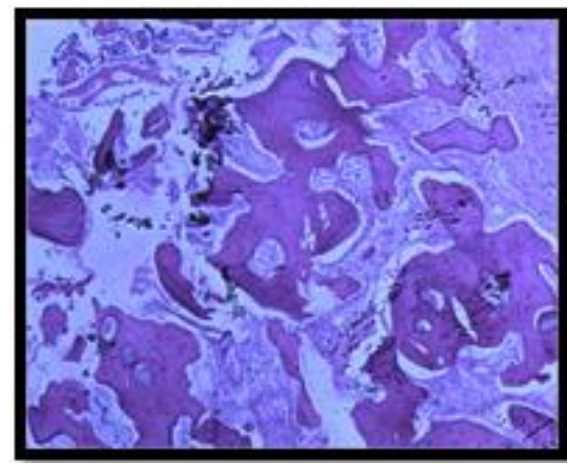

Fig. 6: HPE- 4 X Hematoxylin and Eosin Staining showing typical features of osteoma

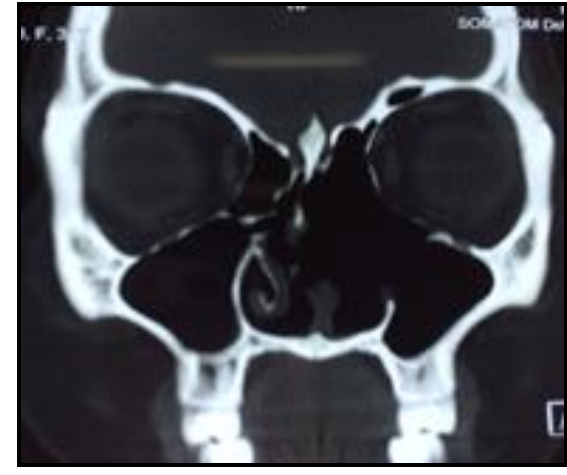

Fig. 7: Post-operative CT scan done 6 months later showed no evidence of residual disease

DISSCUSSION: Osteomas is most commonly seen in the third to fifth decade of life. The male to female ratio is approximately 3:1.(4) Fronto-ethmoid osteomas though frequent, giant osteomas in these sinuses is relatively rare.(5) Tumors larger than $3 \mathrm{~cm}$ in diameter are considered as giant tumors.(6) These osteomas are usually slow growing and asymptomatic. According to Koivunen et al, the mean rate of growth of the paranasal sinus osteomas is $1.61 \mathrm{~mm} /$ year.(7) Ethmoid osteomas can expand to involve the orbit and skull base causing ophthalmologic or neurological complications.(8) The etiology of paranasal sinus osteomas are developmental, infectious or traumatic. ${ }^{(9)}$ Histologically, osteomas are composed of variable amounts of compact and cancellous bone. They are subdivided into ivory and mature types depending on the proportions of dense and cancellous bone.(10) The clinical manifestations of sinonasal osteomas are due to their mass effect such as pain, headache, facial distortion, proptosis, and visual changes. CT is the method of choice for radiological diagnosis as it shows the bony borders, erosions and soft tissue involvement.(11)

Asymptomatic osteomas should be regularly followed up.(12) Indications for surgery are 1) rapid growth of the tumor, 2) the presence of symptoms, 3) chronic rhino sinusitis due to obstruction by the tumor, 4) tumor causing bone erosion or facial deformity, 5) if tumor occupies more than $50 \%$ of the frontal sinus, 6) tumor causing blockage of the frontal recess and 7) the presence of complications. ${ }^{(13,14)}$

The external surgical approaches for osteomas include lateral rhinotomy, osteoplastic flap technique and direct anterior surgical approach. These techniques though effective, have chances of permanent scar formation, mucocele formation and paresthesia.(15,16)

Endoscopic approach for excision of paranasal sinus osteomas, offers a minimally invasive alternative, The advantage being excellent cosmetic results, shorter duration of operative time, and allows closer and more direct visualization during surgery.(17) In case of large osteomas that are broadly attached to the surrounding borders, can be reduced in size with the help of intranasal drilling.(18) Endoscopic management of osteomas of the paranasal sinuses reduces the overall morbidity without sacrificing outcome. $(19,20)$ 
SUMMARY: Endoscopic approach with intranasal drill is a better option for surgical management of giant osteomas of nose and paranasal sinus compared to open technique as this approach reduces morbidity, minimize soft tissue dissection, reduces length of hospital stay, gives a better cosmetic results.

\section{REFERENCES:}

1. Maiuri F, Iaconetta G, Giamundo A, et al. Fronto-ethmoidal and orbital osteomas with intracranial extension. Report of two cases. J Neurosurg Sci 1996; 40: 65-70 PMID: 8913963.

2. Goldenberg D, Gilboa M, Danino J, et al. A large ethmoido-orbital osteoma presenting with epiphora in an 11-year-old boy. J Pediatr Ophthalmolog 2000; 37: 238-40 PMID: 10955549.

3. Menezes C, Davidson T: Endoscopic resection of the spheno-ethmoid osteoma: a case report. Ear Nose Throat J 1994, 73:598-600.

4. Schick B, Steigerwald C, E; Rahman El Tahan A, Draf W. The role of endonasal surgery in the management of frontoethamoidal osteomas. Rhinology 2001: 39: 66-70.

5. Koyuncu J, Belet U, Sesen T: Huge osteoma of the frontoethmoidal sinus with secondary brain abscess. Auris Nasus Larynx 2000, 27: 285-2287.

6. Summers L, Mascott C, Tompkins J, Richardson D: Frontal sinus osteoma associeted with cerebral abscess formation: a case report. Surg Neurol 2001, 55: 235-239.

7. Koivenen P. Lopponen H, Fors AP, Jokinen k. The growth rate of osteomas of paranasal sinuses. Clin Otolaryngol 1997: 22: 111-4.

8. Savic D, Djeric D: Indications for the surgical treatment of osteomas of the frontal and ethmoid sinuses. Clin Otolaryngology 1990, 15: 397-404.

9. Summers LE, Mascot CR, Tompkins JR, Richardson DE: Frontal sinus osteoma associated with cerebral abscess formation: a case report. Surg Neurol 55: 235-239, 2001

10. Fu YS, Perzin KH. Non-epithelial tumors of the nasal cavity, paranasal sinuses,and nasopharynx: a clinicopathologic study: II. Osseous and fibro-osseous lesions, including osteoma, fibrous dysplasia, ossifying fibroma, osteoblastoma, giant cell tumor, and osteosarcoma. Cancer. 1974; 33: 1289-1305.

11. Vowles RH, Bleach NR. Imaging case study of the month: Frontoethmoid osteoma. Ann. Otol. Rhinol. Laryngol 1999; 108: 522-4.

12. Mansour AM, Salti H, Uwaydat S, Dakroub R, Bashshouur Z. Ethmoid sinus osteoma presenting as epiphora and orbital cellulitis: case report and literature review. Surv Ophthalmol 1999; 43: 413-426.

13. B Schick, C Steigerwald, A el Rahman el Tahan, W Draf (2001) The role of endoscopic surgery in the management of frontoethmoid osteomas. Rhinology 39: 66-70.

14. Draf W (2005) Endonasal frontal sinus drainage type I-III according to Draf. In Kountaks S, Seniro B, Draf W. editors. The frontal sinus. (1 ${ }^{\text {st }}$ ed.) New York: Springer 219-231.

15. Seiden AM, El Hefny YI. Endoscopic trephenation for the removal of frontal sinus osteoma. Otolaryngol Head Neck Surg 1995; 112: 607-611.

16. Akmansu H, Eryilmaz A, Dagli M, Korkmaz H. Endoscopic removal of paranasal sinus osteoma: A case report. J Oral Maxillofac Surg 2002; 60: 230-232.

17. Huang HM, Liu CH, Lin KN, Chen HAT. Giant ethmoid osteoma with orbital extension, a nasoendoscopic approach using an intranasal drill. Laryngoscope 2001; 111: 430-432. 


\section{CASE REPORT}

18. Reiss M. Huttenbrink KB. Endoscopic removal of osteoma of the paranasal sinuses. HNO 1997; 45: 233-6.

19. Rokade A, Sama A (2012) Update on management of frontal sinus osteoma. Curr Opin Otolarygol Head Neck Surg 20: 40-44.

20. Ledderose GJ, Betz CS, Steleter K, Leunig A (2011) Surgical management of osteoma of the frontal recess and sinus: extending the limits of the enodoscopic approach. Eur Arch Otorhinolaryngol 268: 525-532.

\section{AUTHORS:}

1. Somu L.

2. Prasanna Kumar S.

3. Ravi Kumar A.

4. Shameem Shinaz

\section{PARTICULARS OF CONTRIBUTORS:}

1. Professor, Department of ENT, Head Neck Surgery, Sri Ramachandra Medical College, Porur, Chennai.

2. Associate Professor, Department of ENT, Head Neck Surgery, Sri Ramachandra Medical College, Porur, Chennai.

3. Director and Professor, Department of ENT, Head Neck Surgery, Sri Ramachandra Medical College, Porur, Chennai.
4. Resident, Department of ENT, Head Neck Surgery, Sri Ramachandra Medical College, Porur, Chennai.

\section{NAME ADDRESS EMAIL ID OF THE CORRESPONDING AUTHOR:}

Dr. Major Prasanna Kumar S, \# 65/2, East Colony,

ICF, Chennai-38.

Email: sprasannakumar10@gmail.com

Date of Submission: 01/12/2014.

Date of Peer Review: 02/12/2014.

Date of Acceptance: 04/12/2014.

Date of Publishing: 08/12/2014. 